Article

\title{
Domestic Gardens Mitigate Risk of Exposure of Pollinators to Pesticides-An Urban-Rural Case Study Using a Red Mason Bee Species for Biomonitoring
}

\author{
Martin Šlachta ${ }^{1, *(0)}$, Tomáš Erban ${ }^{2}\left(\mathbb{D}\right.$, Alena Votavová $^{3}$, Tomáš Bešta ${ }^{4}$, Michal Skalský $^{5}$, \\ Marta Václavíková ${ }^{6}$, Tat'ána Halešová ${ }^{6}$, Magda Edwards-Jonášová ${ }^{1}$, Renata Včeláková ${ }^{1}$ \\ and Pavel Cudlín ${ }^{1}$ \\ 1 Global Change Research Institute of the Czech Academy of Sciences, Lipová 1789/9, \\ 37005 České Budějovice, Czech Republic; edwards.m@czechglobe.cz (M.E.-J.); \\ vcelakova.r@czechglobe.cz (R.V.); Cudlin.p@czechglobe.cz (P.C.) \\ 2 Crop Research Institute, Drnovská 507/73, 16106 Praha 6-Ruzyně, Czech Republic; arachnid@centrum.cz \\ 3 Agricultural Research, Ltd., Zahradní 1, 66441 Troubsko, Czech Republic; votavova@vupt.cz \\ 4 Institute of Hydrobiology of the Czech Academy of Sciences, Na Sádkách 702/7, \\ 37005 České Budějovice, Czech Republic; bobiz@seznam.cz \\ 5 Research and Breeding Institute of Pomology Holovousy Ltd., Holovousy 129, \\ 50801 Hořice, Czech Republic; Michal.SKALSKY@vsuo.cz \\ 6 ALS Limited, ALS Czech Republic, Na Harfě 336/9, 19000 Praha 9-Vysočany, Czech Republic; \\ marta.vaclavikova@alsglobal.com (M.V.); tatana.halesova@alsglobal.com (T.H.) \\ * Correspondence: martin.slachta@seznam.cz
}

Received: 26 September 2020; Accepted: 10 November 2020; Published: 12 November 2020

\begin{abstract}
Domestic gardens supply pollinators with valuable habitats, but the risk of exposure to pesticides has been little investigated. Artificial nesting shelters of a red mason bee species (Osmia bicornis) were placed in two suburban gardens and two commercial fruit orchards to determine the contamination of forage sources by pesticides. Larval pollen provisions were collected from a total of 14 nests. They consisted mainly of pollen from oaks ( $65-100 \%$ weight/sample), Brassicaceae ( $\leq 34 \%$ $\mathrm{w} / \mathrm{s})$ and fruit trees $(\leq 1.6 \% \mathrm{w} / \mathrm{s})$. Overall, 30 pesticides were detected and each sample contained a mixture of 11-21 pesticide residues. The pesticide residues were significantly lower in garden samples than in orchard samples. The difference was attributed mainly to the abundant fungicides pyrimethanil and boscalid, which were sprayed in fruit orchards and were present on average at $1004 \mathrm{ppb}$ and $648 \mathrm{ppb}$ in orchard samples, respectively. The results suggested that pollinators can benefit from domestic gardens by foraging from floral sources less contaminated by pesticides than in adjacent croplands.
\end{abstract}

Keywords: Osmia bicornis; urban green space; wild bees; fungicides; insecticides; pyrimethanil; boscalid; thiacloprid; acetamiprid

\section{Introduction}

There are more than 500 species of wild bees (Hymenoptera: Anthophila, including solitary bees and bumblebees) in Central Europe [1]. Habitat loss and fragmentation driven by agricultural intensification and urbanization, along with exposure to agrochemicals and other factors, have caused a decline of wild bees in developed countries [2-6]. The loss of bee pollinators has adverse effects on ecological systems and crop productivity $[7,8]$.

Green infrastructure in urban environments, such as parks, cemeteries, gardens, and flower beds, provide pollinators valuable refugia, with species richness comparable to habitats in rural areas [9-12]. 
Bees spread from urban refugia to forage in peri-urban agricultural land, where they may contribute to crop production by pollination $[11,13]$. Their pollination service is also important for yields of urban crops, mainly in view of the expanding field of urban agriculture and increased demand for local and sustainable food in cities [13-16].

Bees are exposed to pesticides via pollen, nectar and water consumption [17-21], potentially by soil material used for nest construction [22-24]. They may encounter acute or chronic toxic effects of pesticides [25-27], or indirect impacts through affecting the beneficial bee gut microbiome [28-33] and the resistence to pathogens [34-37] or reduced forage sources in the landscape owing to the use of herbicides [38]. Risk assessment of acute exposure to pesticides used to be generally performed on honeybees [39]. The sublethal effects on the vitality of individuals, colonies or populations of wild bees resulting from longterm chronic exposures are examined less frequently and are, therefore, insufficiently understood [27,40-48]. Pesticides are also applied in urban areas, but the risk of exposing pollinators to them has not been much investigated $[18,49]$. Insecticides were already present in pollen from ornamenal flowers by the time they were sold to customers [50].

The goal of this study was to contribute to the knowledge on the role of domestic gardens for pollinators' communities. We focused on gardens located at the intersection between the urban and rural space. Domestic gardens are defined as an area adjacent to a domestic dwelling [51]. Aside from the benefits in terms of human health and well-being, air cooling or support of biodiversity [12,13,52-54], the misuse of fertilizers and pesticides in domestic gardens [55], out of any institutional control, may pose a risk to pollinators. On the other hand, a lower intensity of agrochemicals use in gardens than in the agricultural landscape could be expected on the basis of earlier research $[18,49]$. We assumed that domestic gardens supply pollinators floral sources less contaminated by pesticides than commercial croplands, represented by fruit orchards, oilseed rape and cereal fields. We expected that the different intensity of chemical treatments in gardens would be reflected in the rates of contamination of larval provisions of an indicator bee species [18,49].

\section{Materials and Methods}

\subsection{Experimental Bee Species}

In this study we used a red mason bee species, Osmia bicornis (Linnaeus, 1758), for monitoring the rates of exposure to pesticides from forage sources. This species has already been used for monitoring the rates of exposures to pesticide in oilseed rape fields [42,45,46,56-59] and for laboratory testing of sublethal effects of insecticides on bee survival $[41,47,48,60]$. It is a food generalist, which feeds preferentially on pollen from oak (Quercus sp.), maple (Acer sp.), horse chestnut (Aesculus hippocastanum) and buttercup (Ranunculus sp.) and on nectar from diverse floral sources, mainly Rosaceae (including fruit trees) and Brassicaceae (including oilseed rape) [61-66]. The collected pollen and nectar are mixed by females in a pollen loaf and served as food for a brood, referred to as larval (food) provision. We chose this species instead of the generally used honeybee because it forages for shorter distances than the honeybee $[67,68]$ and is, thus, a better proxy for wild bees and other pollinator taxa (e.g., Diptera, Lepidoptera).

\subsection{Study Sites}

The study was conducted in South Bohemia, Czechia at an altitude of 450-500 m a.s.l. The experimental area consisted of a mosaic of villages and small towns, arable fields, fruit orchards, ponds and forests, forming a rural landscape typical for this part of the country. České Budějovice, the largest city in the region (nearly 100,000 inhabitants) and the region's administrative center, was about $30 \mathrm{~km}$ away from the focus area.

Four experimental sites were selected for biomotoring using Osmia bicornis (Figure 1; Supplementary Materials Table S1; Figure S1). 


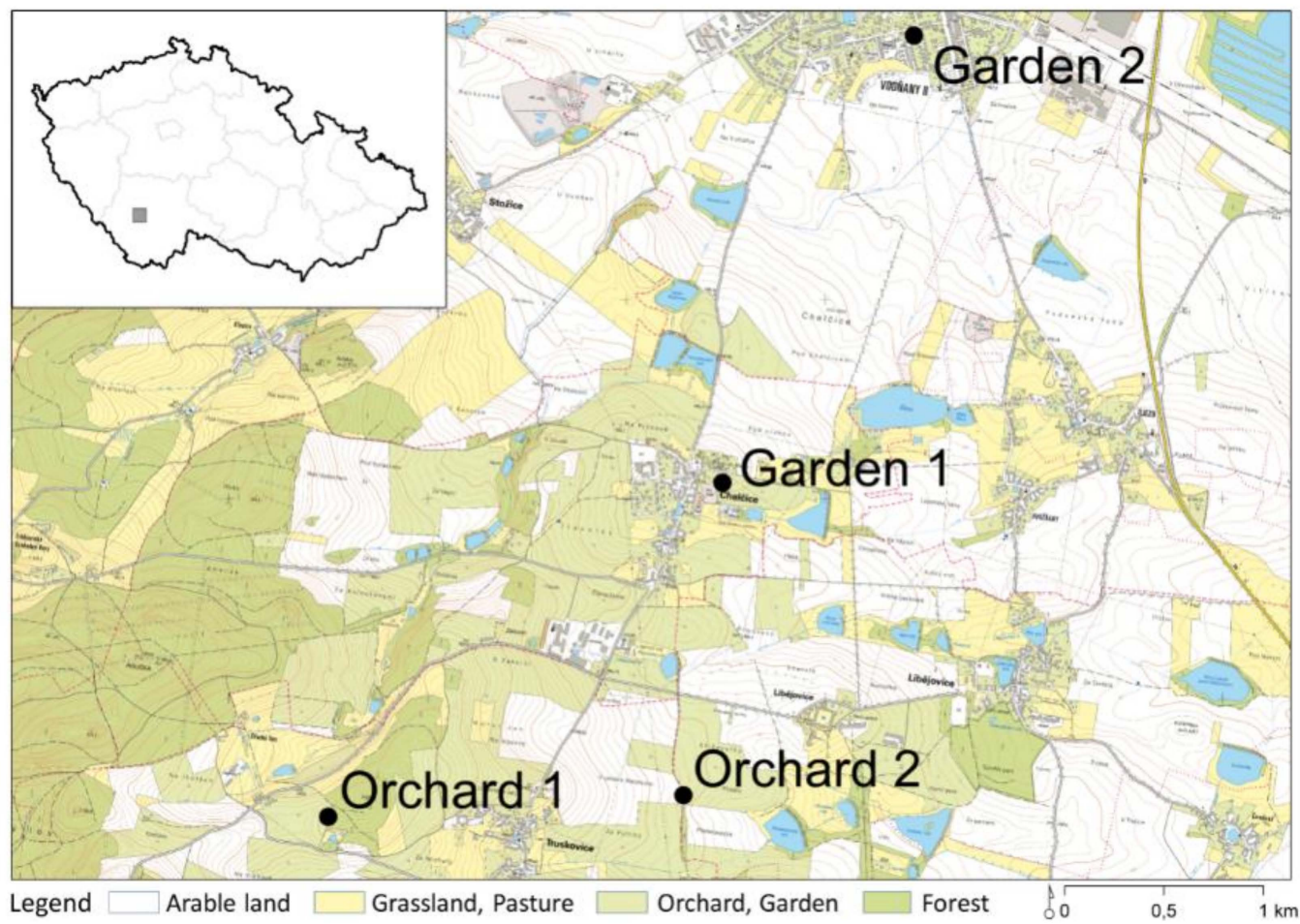

Figure 1. Map of the study area with four experimental sites where shelters with nests of Osmia bicornis were located [69].

Two sites were at the edge of commercial fruit orchards in the vicinity of Chelčice (Orchard 1-2), while the other sites were two domestic gardens, one located directly on the edge of Chelčice (Garden 1), and the other in a suburban area of Vodňany about $2 \mathrm{~km}$ away from Chelčice (Garden 2). The population of Chelčice is about 400, and Vodňany has about 7000 inhabitants. The gardens sites were 100 and $230 \mathrm{~m}$ distant from chemically treated crops (Garden 1 and Garden 2, respectively). The distances of the orchard sites from domestic gardens were 250 and $630 \mathrm{~m}$ (Orchard 1 and Orchard 2, respectively). Intensive production of apples, plums, cherries, sour cherries, and red currants has been practised in the surroundings of Chelčice for more than 50 years. Most of the commercial orchards in the area, about 450 ha in total, plus arable fields, are managed by a major local fruit producer. The nesting shelters of Orchard 1 and 2 were located at the edge of his orchards (apple and plum orchard, respectively). This producer provided us a schedule of chemical treatments in his orchards and adjacent oilseed rape fields (Supplementary Materials Table S2). Information on chemical treatments in domestic gardens and orchards of minor growers was not gathered due to their high number in the perimeter accessible by the foraging flight of the monitored bees (up to $1 \mathrm{~km}$ ) $[67,68]$.

\subsection{Collection of Pollen Samples}

Nesting shelters for mason bees were installed in the experimental sites in March 2019. Shelters consisted of a wooden cage placed on stakes about $1 \mathrm{~m}$ above the ground which contained blocks of wooden notched boards $(15 \times 22 \times 2 \mathrm{~cm})$ piled on top of each other forming successive holes (diameter $8 \mathrm{~mm}$, length $22 \mathrm{~cm}$ ). The boards were fixed by screws so that the nesting blocks could be opened, and larval provisions could be collected from the brood cells. One hole was occupied by one female and contained one nest, which consisted of a series of brood cells separated by loam partitions and filled by larval food provisions. Overwintered mason bee adults hidden in their coccoons were placed inside the nesting shelters in mid-April and left to emerge (coccoons were on disposal from another experiment). The nesting activity of bees started by 20 April, being temporarily reduced from 27-30 April and 3-7 May due to cold weather. The nests were opened and the latest built brood 
cells were marked by the marker pen on April 26 (Garden 1, Orchard 2) and April 29 (Orchard 1). The Garden 2 nests were not inspected in this way. On May 13, larval provisions, added since the dates of inspection, were collected. Each sample consisted of provisions collected from several brood cells inside one nest. In the laboratory, every pollen sample was manually homogenized using tweezers and placed into a freezer $\left(-80^{\circ} \mathrm{C}\right)$ until further processing.

\subsection{Palynological Analyses}

Pollen composition was analyzed in a part of each sample. Samples were processed through incubation in $10 \% \mathrm{KOH}$ and an acetolytic mixture (acetic acid anhydride and sulphuric acid 1:9) in order to prepare them for taxonomic classification [70,71]. At least 500 grains were counted per sample using an Olympus BX 51 light microscope at a magnification of 1000x.

\subsection{Pesticide Analyses}

In total, 96 pesticides and their metabolites were analyzed in the pollen samples (Supplementary Materials Table S3). Analytical standards and isotopically labeled internal standards (ISTD) were purchased from Neochema $\mathrm{GmbH}$, and the other chemicals were purchased from Sigma Aldrich. ISTD were applied for quality control of the analyses and final compound quantification. With regard to the difficulty of the pollen matrix, the analytical method was optimized and validated for this specific type of samples. Not all active substances applied in the study sites could be detected by the used analytical method. Not-analyzed substances were: methoxyfenozide, tetraconazole, metiram, fosetyl-AL, dithianon, captan, cyflufenamid, pyraclostrobin, glyphosate, mancozeb, isopyrazam, arylex, clopyralid, and cypermethrin. Samples were stored at $-80^{\circ} \mathrm{C}$ prior to the analyses.

For LC-MS analyses, pollen samples were prepared by the principles of the QuEChERS extraction and purification process [72]. Briefly, for extraction, $1 \mathrm{~g}$ of pollen was weighed into a 50-mL centrifuge tube and a mixture of ISTD (100 $\mu \mathrm{L}$ of ISTD solution at concentration $100 \mathrm{ng} / \mathrm{mL})$ was added to the samples. Then, $6 \mathrm{~mL}$ of Milli-Q water and $10 \mathrm{~mL}$ of acetonitrile were added to the sample and shaken on an automatic rotary shaker for $10 \mathrm{~min}$. After this first part of the extraction, $3 \mathrm{~mL}$ of hexane was added and shaken again for $5 \mathrm{~min}$ on a rotary shaker. The tube was let to stand for $10 \mathrm{~min}$. Subsequently, $4 \mathrm{~g} \mathrm{MgSO}_{4}, 1 \mathrm{~g} \mathrm{NaCl}, 1 \mathrm{~g} \mathrm{Na}_{3} \mathrm{C}_{6} \mathrm{H}_{5} \mathrm{O}_{7} 2 \mathrm{H}_{2} \mathrm{O}$, and $0.5 \mathrm{~g} \mathrm{Na}_{2} \mathrm{C}_{6} \mathrm{H}_{5} \mathrm{O}_{7} 1.5 \mathrm{H}_{2} \mathrm{O}$ salts were added to the extract. The tube was immediately shaken vigorously by hand and centrifuged for $5 \mathrm{~min}$ at $8944 \times g$. An $8 \mathrm{~mL}$ aliquot of the acetonitrile-layer was taken and purified again by the addition of $0.9 \mathrm{~g} \mathrm{MgSO} 4$, $0.15 \mathrm{~g}$ PSA, and $0.15 \mathrm{~g} \mathrm{C18}$, which was then mixed by $1 \mathrm{~min}$ of hand shaking. The purified sample extract was centrifuged again for $5 \mathrm{~min}$ at $8944 \times \mathrm{g}$. Aliquots of the extract $(2 \mathrm{~mL}$ each) were taken, evaporated to dryness by a gentle stream of nitrogen, and dissolved again in $1 \mathrm{~mL}$ of $5 \mathrm{mM}$ ammonium acetate/acetonitrile $(80 / 20, v / v)$ for LC-MS analyses of multi-residue pesticides. Samples were passed through $0.22 \mu \mathrm{m}$ filters prior to LC-MS analyses.

Target analytes were separated and detected by liquid chromatography (Acquity UPLC I-Class, Waters, Milford, MA, USA) coupled to a tandem mass spectrometer (XEVO TQ-XS, Waters, Milford, MA, USA). For LC separation of all compounds, an Acquity UPLC BEH C18 $1.7 \mu \mathrm{m}$ $(2.1 \times 100 \mathrm{~mm})$ analytical column was used. Column temperature was set at $40{ }^{\circ} \mathrm{C}$, with $100 \mu \mathrm{L}$ injection volume of the samples. A gradient elution by $5 \mathrm{mM}$ ammonium acetate (A) and $\mathrm{MeOH}(\mathrm{B})$ of analytes was applied.

The MS detection of analytes was done by tandem mass spectrometry (MS/MS), equipped with an electrospray operating in both positive and negative ionization modes (ESI+). The MS operated with the following parameters: capillary voltage $(1500 \mathrm{~V})$, cone voltage (specific for each analyte, range 15-35 V), desolvation temperature $\left(550{ }^{\circ} \mathrm{C}\right)$, source temperature $\left(150{ }^{\circ} \mathrm{C}\right)$, desolvation gas $(1000 \mathrm{~L} / \mathrm{Hr})$. Analytes were identified by retention time and specific MRM transitions. The UHPLC-MS/MS system was controlled using MassLynx software (v. 4.1; Waters), and the data were evaluated using TargetLynx software (v. 4.1; Waters) and additional Excel data processing. 
Method validation was proceeded on blank pollen samples, which were spiked with a mixture of the target pesticides at two different levels $(1$ and $10 \mu \mathrm{g} / \mathrm{kg}$ ) in five replicates. Data obtained by analyses of spikes were used for calculating basic validation parameters: limits of detection (LOD), limits of quantification (LOQ), method linearity, repeatability (below 16\% for all analytes), recoveries $(75-116 \%)$, and final uncertainties (up to $23 \%$ of expanded uncertainties). The LOQ was $10 \mu \mathrm{g} / \mathrm{kg}$ (10 ppb) for all the analyzed substances. The LODs are given in the Supplementary Materials Table S3.

\subsection{Statistical Evaluation}

The concentrations below LOQ were included only in the comparisons of the number of pesticides in the samples. In the quantitative comparisons, the concentrations $\geq$ LOQ were used and the concentrations below LOQ were considered to be zero in the calculations. Between-environment (garden vs. orchard) differences in the number and concentration of pesticides were tested by the Mann-Whitney-Wilcoxon test in R 3.6.2. [73].

\section{Results}

\subsection{Composition of Pesticide Residues}

Fourteen samples of larval provisions, five in the garden sites and nine in the orchard sites, were collected and analysed. In total, 30 pesticide residues ( 11 herbicides, 11 fungicides, 6 insecticides, and 2 pesticide metabolites) were identified in the samples (Figure 2; Table 1; Supplementary Materials Table S4). Each sample contained 11-21 pesticide residues (Supplementary Materials Tables S5 and S6). Five residues (17\% of total number) were common in all experimental sites, while 18 residues $(60 \%$ of total number) were common in the garden and orchard environments. The total number of residues was significantly higher in the orchards than in gardens $(U=5.5 ; Z=-2.2 ; p<0.05$; mean in orchards = 17; mean in gardens $=13$ ).

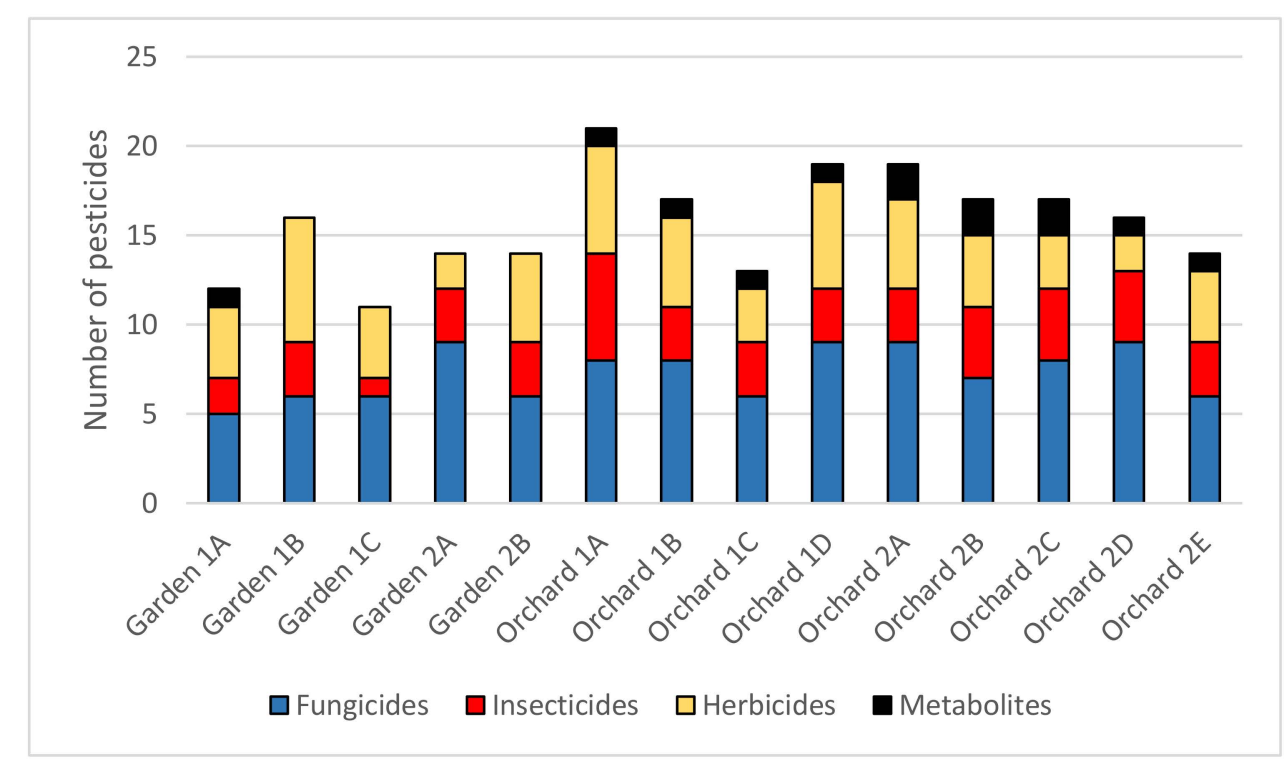

Figure 2. Number of pesticides in larval provisions of the red mason bee (concentrations $<$ limits of quantification (LOQ) were also included in the calculation). 
Table 1. Pesticides with the concentration over the limit of quantification (LOQ = $10 \mathrm{ppb}$ ) in larval provisions of the red mason bee. They comprise the fungicides (pyrimethanil, boscalid, tebuconazole, azoxystrobin, prochloraz), the herbicide (terbuthylazine), and the insecticides (acetamiprid, thiacloprid, methiocarb).

\begin{tabular}{|c|c|c|c|c|c|c|c|c|c|c|c|c|c|c|}
\hline \multirow[t]{2}{*}{ Site } & \multirow[t]{2}{*}{ Nest } & \multicolumn{9}{|c|}{ Concentration of Pesticides (ppb) } & \multicolumn{4}{|c|}{ Composition of Pollen (\%) } \\
\hline & & Pyrimet. & Boscalid & Tebuc. & Azoxys. & Prochloraz & Terbuthyl. & Acetamip. & Thiaclop. & Methiocarb & Quercus T & PM $^{1}$ & Bra. & Other \\
\hline \multirow[t]{3}{*}{ G 1} & $\mathrm{~A}$ & 76.2 & & & & & & & & & 99.6 & & & 0.4 \\
\hline & $\mathrm{B}$ & 417.0 & & 13.7 & & & & 12.2 & & & 65.2 & 0.2 & 34.2 & 0.4 \\
\hline & $\mathrm{C}$ & 51.6 & & 12.7 & & & & & & & 99.6 & & 0.4 & \\
\hline \multirow[t]{2}{*}{ G 2} & A & & & & & & 14.5 & & & & 73.9 & 0.2 & 1.4 & 24.5 \\
\hline & $\mathrm{B}$ & & & & & & & & & & 93.5 & & 6.3 & 0.2 \\
\hline \multirow[t]{4}{*}{$\mathrm{O} 1$} & A & 1677.9 & 1603.1 & 86.9 & 19.7 & 18.5 & & & & & 97.0 & 1.6 & 1.0 & 0.4 \\
\hline & $\mathrm{B}$ & 312.0 & 106.7 & 14.6 & & & & & & & 99.0 & 0.2 & 0.4 & 0.4 \\
\hline & $\mathrm{C}$ & 437.3 & 730.8 & 15.7 & 14.8 & & & & & & 92.0 & 0.2 & 7.6 & 0.2 \\
\hline & $\mathrm{D}$ & 254.5 & 1359.5 & 11.4 & 275.0 & & & & & & 95.3 & & 4.7 & \\
\hline \multirow[t]{5}{*}{$\mathrm{O} 2$} & A & 631.2 & 31.3 & 27.7 & 290.4 & & & 10.7 & 10.9 & & 83.4 & 0.2 & 16.4 & \\
\hline & B & 846.7 & 205.6 & 52.9 & & & & & & & 91.0 & & 1.4 & 7.6 \\
\hline & $\mathrm{C}$ & 2424.6 & 37.2 & 11.1 & & & & & & 18.5 & 95.3 & & 4.3 & 0.4 \\
\hline & $\mathrm{D}$ & 2446.3 & 375.7 & 215.9 & & & & 18.8 & & & 66.3 & & 33.3 & 0.4 \\
\hline & $\mathrm{E}$ & 10.2 & 1383.9 & 407.9 & & & & & & & 100.0 & & & \\
\hline \multirow[t]{2}{*}{ Mean $^{2}$} & & $109.0(\mathrm{G})$ & $0.0(\mathrm{G})$ & $5.3(\mathrm{G})$ & $0.0(\mathrm{G})$ & & & & & & & & & \\
\hline & & $1004.5(\mathrm{O})$ & $648.2(\mathrm{O})$ & $93.8(\mathrm{O})$ & $66.7(\mathrm{O})$ & & & & & & & & & \\
\hline$M-W^{3}$ & & $\mathrm{G}<\mathrm{O}^{*}$ & $\mathrm{G}<\mathrm{O}^{* *}$ & $\mathrm{G}<\mathrm{O}^{*}$ & ns & & & & & & & & & \\
\hline Mean ${ }^{4}$ & & 14.2 & 22.5 & 16.5 & 7.7 & & & & & & & & & \\
\hline Maxim. & & 83.0 & 962.0 & 33.2 & 107.0 & & & & & & & & & \\
\hline
\end{tabular}

${ }^{1}$ PM-Prunus sp., Malus sp; Bra.-Brassicaceae; ${ }^{2}$ Mean concentration in garden- $\mathrm{G}(n=5)$ and orchard-O $(n=9)$ samples; values $<\mathrm{LOQ}$ were considered to be zero; ${ }^{3}$ Man
U-test: $p<0.01^{* *} ; p<0.05^{*} ; p>0.05 \mathrm{~ns} ;{ }^{4}$ Mean and maximum concentration of pesticides (ppb) recorded in pollen of honeybees worldwide [39] given for the comparison. 


\subsection{Quantitative Comparisons of Pesticides}

The total amount of pesticide residues (sum of their concentrations $\geq$ LOQ) was significantly higher in the orchard samples than in the garden samples $(U=5 ; Z=-2.1 ; p<0.05$; Figure 3; Supplementary Materials Tables S5 and S6). Four fungicides, pyrimethanil, boscalid, tebuconazole, and azoxystrobin, contributed $\geq 98 \%$ of the total contents of pesticides (with concentrations $\geq$ LOQ) in the orchard samples, $97-100 \%$ in the Garden 1 samples, and $0 \%$ in the Garden 2 samples. When tested separately, pyrimethanil, boscalid, and tebuconazole had significantly higher levels in the orchard samples than in the garden samples $(p<0.05$; Table 1$)$.

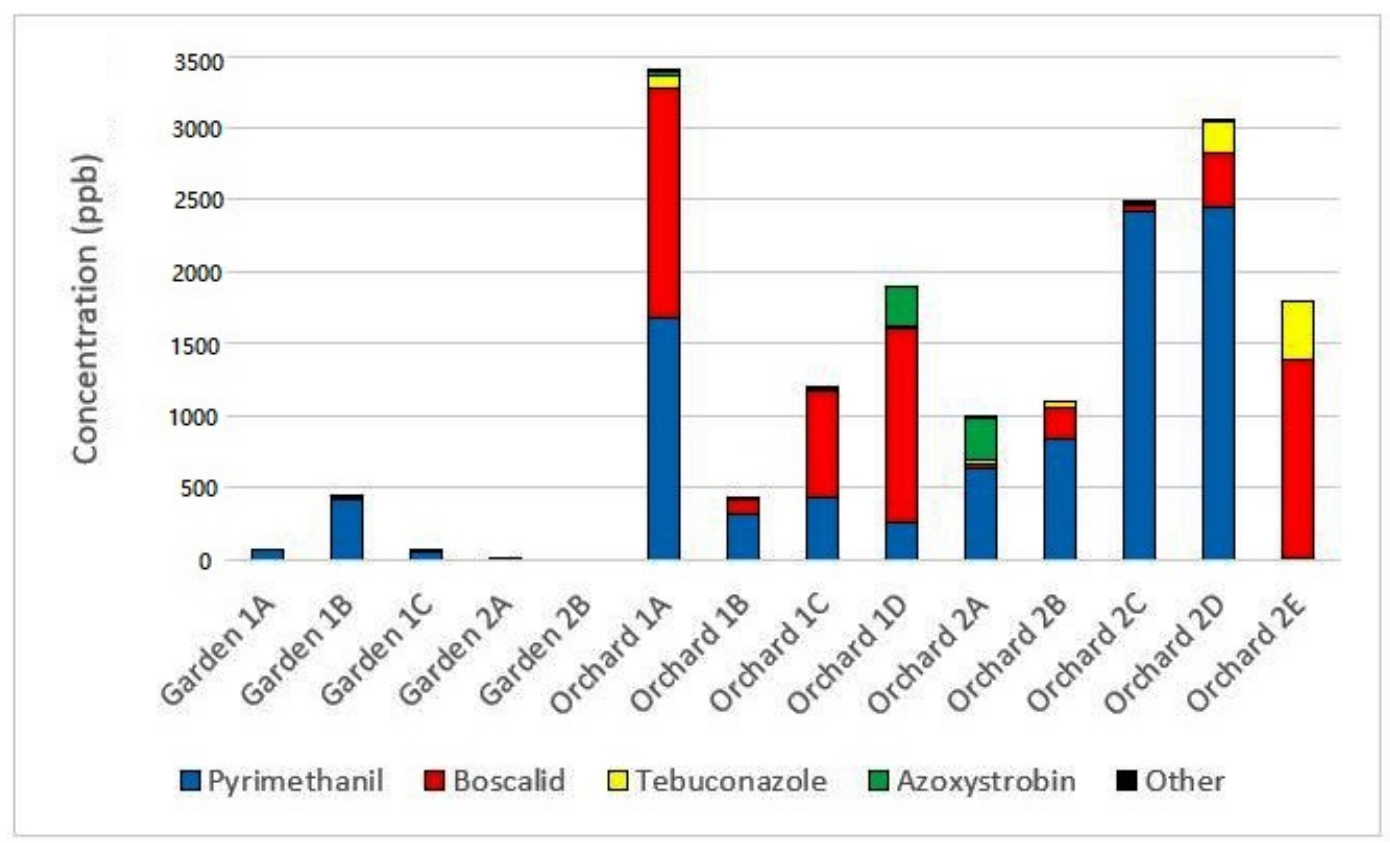

Figure 3. Concentrations of four dominant fungicides and the sum of other pesticides $(\mathrm{ppb}=\mathrm{ng} / \mathrm{g}=\mu \mathrm{g} / \mathrm{kg}$ ) in larval provisions of the red mason bee (only the concentrations $\geq$ LOQ were included in the calculation).

Three insecticides with a concentration over the LOQ (acetamiprid, thiacloprid, methiocarb) were present in the samples, mostly in the orchard samples (except one record of acetamiprid in a Garden 1B sample; Table 1).

\subsection{Plant Species Composition of Pollen}

Pollen was collected mainly from oaks (Quercus T-pollen type), forming 65-100\% of the total counts in the samples (Table 1). Pollen from fruit trees (Prunus sp., Malus sp.) comprised only up to $1.6 \%$ of the total counts. Brassicaceae pollen (potentially oilseed rape) formed more than one third of the total counts in some samples, but its content varied substantially between samples even from the same experimental site. Non-crop pollen types were represented by Juglans ( $23 \%$ in a Garden $2 \mathrm{~A}$ sample), Ranunculus acris $\mathrm{T}$ ( $7.6 \%$ in an Orchard 2B sample), and the following, which comprise less than $0.5 \%$ of the total counts: Betula, Sorbus T, Aesculum hippocastanum, Pinus sylvestris T, Centaurea jacea T, Crepis T, Asteraceae-Fenestrateae, and Trifolium repens $\mathrm{T}$.

\section{Discussion}

\subsection{Rates of Pesticide-Contamination in Gardens vs. Orchards}

Our results confirm the findings of other authors that pollinators are exposed to a broad range of pesticides in agricultural landscapes, as indicated by honeybee pollen provisions [74-77], bumblebee pollen provisions and bodies [18,49], or bodies of solitary bees [78]. This is worrisome 
because their functional interactions are not well known [79]. The synergistic increase in the toxicity of some pyrethroid and neonicotinoid insecticides in response to the presence of Ergosterol Biosynthesis Inhibitor (EBI) fungicides was documented in honeybees [80-83] and mason bees [46,83-85].

From a total of 30 pesticide residues recorded in larval provisions of the red mason bee, a majority of them $(n=18 ; 60 \%)$ were common in both the garden and orchard environments. However, the orchard samples contained them in significantly higher amounts, owing mainly to higher concentrations of three dominant fungicides (pyrimethalin, boscalid, and tebuconazole) in the orchard samples. These results support our presumption that domestic gardens supply pollinators a forage less contaminated by pesticides than the surrounding agricultural landscape.

Similar results were obtained in England by examining the pesticide loads in pollen collected by bumblebees [18]. Nests located in urban gardens contained significantly lower amounts of pesticides in the sampled pollen than nests located in adjacent rural areas. This difference was evident also in the pesticide contents of bumblebee bodies [49]. Solitary bees and bumblebees forage for shorter distances than honeybees. Honeybees forage in a radius of $1.5 \mathrm{~km}$ on average [86], while the mean foraging distances of the red mason bee and five other species of solitary bees ranged from 75 to 125 meters, with a maximum of 800 or 900 meters for the red mason bee [67,68]. Forty percent of workers of the bumblebee species Bombus terrestris foraged up to 100 meters from their nests [87], even when they were able to forage for distances of several kilometers [88]. Owing to limited foraging distances, the quality of local floral resources may strongly determine the vitality of wild bee populations. Indeed, larger populations of bumblebees $[10,11]$ and solitary bees [11] were found in domestic gardens than in rural areas.

Earlier research highlighted the potential of urban green spaces in terms of providing diverse nesting and forage sources to pollinators, which have decreased in rural areas $[5,12]$. On the other hand, the production of crops in peri-urban and urban areas may benefit from a pollination ecosystem service flow from these green refugia $[13,15,54]$. We add new findings on the potential of gardens to provide an enhanced quality of forage resources for pollinators [18,49]. In Czechia, the main reasons for food self-provisioning of gardeners were, first, because they did it as a hobby, and second, because they wanted to obtain healthy and fresh food, and not because they wanted to save money or contribute to environmental protection [52]. Vegetable, fruits, and potatoes contribute each approximately one-third to the self-provisioning of Czech households [89], while currants, strawberries, apples, and cherries are the most frequently grown fruits [90]. Though not recognized by gardeners as a priority, protecting the environment also includes protecting pollinator communities and the pollination ecosystem service to their crops $[8,91]$. Our findings contribute to a broader understanding of how urban gardening generates valuable environmental and social outputs in the cities [12-16,53,54].

\subsection{Source of Exposure to Pesticides}

Larval provisions in orchard nests were strongly contaminated by several fungicides that were sprayed on commercial crops. Pyrimethanil and boscalid were sprayed on blossoming fruit orchards 13 and 7 days prior to sample collection, respectively. Pyrimethalin was applied in apple orchards ( $\leq 50 \mathrm{~m}$ from nests) and boscalid was used in sour cherry orchards (180 and $460 \mathrm{~m}$ from nests in Orchard 1 and Orchard 2, respectively). Pyrimethanil could also be used by minor growers in their apple orchards located 50 and $150 \mathrm{~m}$ from the Orchard 1 and Orchard 2 nests, respectively. Tebuconazole, another dominant fungicide in the samples, was not applied to the orchards, but is sprayed on cereal crops. The mean values of these three compounds in the orchard samples exceeded those reported for the pollen of honeybees worldwide [39] by 71 times (pyrimethalin), by 29 times (boscalid) and by 6 times (tebuconazole). In the garden samples, only the mean concentration of pyrimethanil in Garden 1 (182 ppb) exceeded the mean value reported for honeybee pollen worldwide [39], by 13 times. The commercial apple orchards were $270 \mathrm{~m}$ distant from Garden 1. The fungicide azoxystrobin, also present at a high concentration in orchard samples, was sprayed on oilseed rape 6 days prior to sample collection, 190 and $510 \mathrm{~m}$ from the Orchard 1 and Orchard 2 nests, respectively. It should be 
noted that the five other fungicides that were sprayed on blossoming apple trees (i.e., tetraconazole, metiram, fosetyl-AL, dithianon, pyraclostrobin) or oilseed rape (isopyrazam) were not surveyed in the samples, nor was the herbicide glyphosate, applied to sour cherry and plum orchards at the end of April.

Pollen from oaks dominated all samples. It is possible that it could have been contaminated by pyrimethalin and boscalid during treatments of adjacent fruit orchards. Oaks were common along the forest edges and tree alleys in the near surroundings of the examined orchards. Most of the other pesticides were not sprayed in the orchards, but rather on arable land. Application on arable crops is done in a way that substantially limits the dispersal of pesticides outside the fields. Exposure via nectar, thus, seems to be the most probable for most of the detected residues. The contaminated nectar may have been collected directly from the treated crops (fruits, oilseed rape) or from wildflowers in their surroundings [19]. Pollen and nectar from wildflowers at the edge of oilseed rape fields have been identified as important sources of exposure to pesticides for honeybees and bumblebees $[17,18]$. These contained similar mixtures of pesticides as the pollen from oilseed rape, but generally in lower concentrations. Exposure to pesticides via wild plants in the vicinity of chemically treated crops was also documented in other studies dealing with honeybees [92,93] or with solitary bees [78].

Since oak flowers do not supply nectar, females of the red mason bee must also visit nectar sources during each foraging trip, as indicated by the minority pollen types in the larval provisions [62]. The female bees in our study visited fruit trees and Brassicaceae (potentially oilseed rape), as indicated by the minority pollen types in the samples. However, nectar had been reported to contribute little to larval provisions in the red mason bee $(<4 \%$ weight) [63], and it contained lower concentrations of pesticide residues (namely neonicotinoids) compared to pollen of the same crops [20]. It is unclear if residues would appear in larval provisions in such quantities if they originated solely from nectar sources. In the laboratory experiment, no residues were detected in the larval provisions of the red mason bee after nesting females had been supplied with an artificial nectar containing the neonicotinoid insecticides thiamethoxam (2.87 ppb) and clothianidin $(0.45 \mathrm{ppb})$ (using a gas chromatography mass spectroscopy, GCMS; limit of detection, LOD $=0.1 \mathrm{ppb}$ ) [41].

Other routes of exposure should also be considered, such as direct contamination of bee shelters by pesticide formulation sprayed nearby, intake by water consumption $[20,21,94,95]$, or contact with contaminated soil (loam) that forms a part of nest construction [22-24]. Direct spraying could have taken place in the Orchard 1 (pyrimethanil applied to apple trees) and Orchard 2 sites (boscalid and acetamiprid applied to plum trees). However, high levels of boscalid were also found in Orchard 1, while pyrimethalin also occurred at high concentrations in Orchard 2.

Leaching of pesticides from loam partitions of brood cells into larval food provisions is another possible route of exposure. Loam for the construction of the partitions was collected by bees directly in orchards near the nests (personal observation) and residues of some pesticides are known to persist in agricultural land for years [20]. Moreover, the bees prefer to collect wet particles of soil, which may have been contaminated by pesticides leaching from soil to water [94,95]. Little attention has been paid to this route of exposition so far [22,24]. The adverse effect of the highly toxic imidacloprid on the survival of the adult mason bee Osmia lignaria was observed when they were exposed in the larval stage to contact with a solution containing this substance in a high concentration of $100 \mathrm{ppb}$ [23]. Pesticide residues were surveyed in topsoils ( $<25 \mathrm{~cm}$ soil depth) of arable fields in Czechia in samples collected in February-March [96]. They contained tebuconazole (maximum level $28 \mathrm{ppb}$ ), boscalid (maximum level $29 \mathrm{ppb}$ ), and azoxystrobin (maximum level $23 \mathrm{ppb}$ ) in 36, 7, and $9 \%$ of the total number of samples $(n=75)$, respectively. In another study, pesticide contents were examined in topsoils from different cropping systems in $11 \mathrm{EU}$ member states [97]. Samples were collected in April-October and contained tebuconazole (maximum level $19 \mathrm{ppb}$ ), boscalid (maximum level $41 \mathrm{ppb}$ ), and azoxystrobin (maximum level $25 \mathrm{ppb})$ in 12, 27, and 7\% of the total number of samples $(n=317)$, respectively. Pyrimethalin was not surveyed in any of the mentioned studies. Soil as a route of exposure should be considered also by 
other categories of wild bees since most of them nest directly in soils (e.g., Andrenidae and Halictidae families and bumblebees).

\subsection{Implication for Bee Health}

Fungicides, as well as herbicides, are regarded as safe for bees, since they target different metabolic processes of plants or fungi than insects. Thus, they are applied to blossoming crops and may subsequently appear in high amounts in larval provisions in bee nests. However, there is a lack of knowledge on the effects of fungicides on the fermentation processes in honeybee pollen and on the gut bacterial microbiome [28-30,33]. The herbicide glyphosate was proven to substantially affect the gut microbiome in bees [31,32]. Three fungicides, including boscalid, were found to adversely affect the nesting behavior of the mason bees O. lignaria and Megachile rotundata [98]. Moreover, tebuconazole is an EBI fungicide, the class of fungicides known to synergistically enhance the toxicity of neonicotinoid insecticides [46,80-85]. Four other EBI fungicides were detected in our study: propiconazole (93\% prevalence; levels < LOQ), epoxiconazole ( $93 \%$ prevalence; levels < LOQ), prochloraz ( $36 \%$ prevalence; maximum level $=18.5 \mathrm{ppb})$, and metconazole $(7 \%$ prevalence, i.e., only one record, with the concentration $<\mathrm{LOQ}$ ). Exposure to a tank mixture of the fungicide prochloraz and insecticide thiacloprid under semi-field conditions was evaluated to be highly risky for the red mason bee [46]. Propiconazole has been banned in the EU since March 2020 [99].

Two neonicotinoids were detected in our study, acetamiprid and thiacloprid. Neonicotinoids disrupt the insect nervous system by stimulating nicotin acetylcholine receptors. Even at lower, sublethal doses, they interfere with the navigation, learning ability, and immunity of bees, including mason bees and bumblebees [20,40,100-102]. Acetamiprid was sprayed 17 days and 32 days prior to sample collection on plum and apple trees, respectively. Thiacloprid was sprayed on oilseed rape 26 days prior to sample collection, while the crop was not in bloom at that time, and when the mason bees had not started to forage yet. However, neonicotinoids are known to persist in and to be translocated between plant tissues, including reproductive organs [20]. Moreover, neonicotinoids persist in soils for a long time, after which they can be taken up by the roots of plants [17,92]. Thiacloprid has a dissipation half-time $\left(\mathrm{DT}_{50}\right)$ of up to 74 days in soil, while it is up to 450 days for acetamiprid [20]. Thiacloprid was found in the pollen and nectar of oilseed rape, in soils under oilseed rape crops or in field margins, and in pollen and nectar of wildflowers in field margins, even when this compound had not been applied in these fields in the previous three years [17]. Thiacloprid registration in the EU expired on April 2020 [103].

Chlorpyrifos, an organophosphate insecticide, was present in $86 \%$ of our samples, but in concentrations below the LOQ. It was evaluated to be highly risky for honeybees and bumblebees, because it is highly toxic, has a high prevalence in pollen surveys worldwide, and high concentrations in pollen [39]. Similar to thiacloprid, chlorpyrifos was not renewed in the EU in 2020 [104]. Additionally, methiocarb, which was detected in three orchard samples (with maximum level $18.5 \mathrm{ppb}$ ), has been banned in the EU, since April 2020 [105]. It is a carbamate insecticide used as a seed coating in maize or as a molluscide. We are not aware of the existence of any maize field near the Orchard 1 and 2 sites. It may have, thus, originated from some molluscid application in cropland or domestic gardens. The presence of its metabolite methiocarb-sulfoxide in Orchard 2B and C samples indicates the historical contamination of the sites.

Data on the impacts of chronic exposure to cocktails of residues in mason bee larvae, including their functional interactions, are very scarce [39]. The concentrations of $3.5 \mathrm{ppb}$ [41] and 0.7-10 ppb [20] in nectar were suggested to have the negative impacts on solitary bee reproductive outputs and the ability of bumblebees to collect pollen, respectively, by more toxic neonicotinoids (thiamethoxam, clothianidin, imidacloprid) than those recorded in our study (acetamiprid, thiacloprid; maximum level $18.8 \mathrm{ppb}$ ). The neonicotinoids in our study may be potentially of concern regarding wild bee health when combined with EBI fungicides (e.g., tebuconazole, prochloraz). Like most the other residues, they probably originated from the nectar of crops or nearby wildflowers, rather than from oak pollen. 
Since most of the pollinators are food generalists, their diet choice, at least with regards to nectar sources, may be similar to that of the red mason bee. This suggests that they may also profit from forage sources that are less contaminated by toxic compounds in domestic gardens with positive health consequences.

\section{Conclusions}

Our results confirm earlier findings on the beneficial role of domestic gardens in supporting the biodiversity in urban areas. Using an experimental solitary bee, we demonstrate that pollinators forage from floral sources less contaminated by pesticides when nesting in domestic gardens than in adjacent rural areas. This contribution of urban gardening to biodiversity conservation has not yet been recognised nor investigated, except in two recent British studies dealing with bumblebees [18,49]. The quality of forage sources is important for wild bees, owing to their limited foraging distances. Their populations established in garden refugia pollinate urban crops, the production of which generates valuable socio-economic outputs. More research in this field is needed considering the fact that gardeners use pesticides without any institutional control, which may disfavour them with respect to environmental issues.

Supplementary Materials: The following are available online at http://www.mdpi.com/2071-1050/12/22/9427/s1, Figure S1: Orthophotos of the experimental sites [106], Table S1: The potential sources of pesticide residues in the larval provisions, Table S2: Schedule of pesticide treatments in fruit orchards and oilseed rape fields, Table S3: List of active substances surveyed and recorded, with their LOD, Table S4: List of recorded residues and their prevalence in the samples, Table S5: Concentrations of residues in the samples, Table S6: Number of pesticide residues and the sums of their concentrations in the samples.

Author Contributions: M.Š., T.E., and A.V. conceived and designed the experiment; A.V. and P.C. administrated the project; M.Š. performed the experiment and wrote the main manuscript; T.E., M.V., and T.H. provided pesticide analyses; T.B. provided palynological analyses; M.S., M.E.-J., and R.V. analysed the data; T.E. and P.C. reviewed the manuscript. All authors have read and agreed to the published version of the manuscript.

Funding: This research was funded by the TECHNOLOGY AGENCY OF THE CZECH REPUBLIC (TA CR), grant number TH03030134, by institutional support, MZE-RO1720, and by financial support of the project of the Ministry of Agriculture-RO1520.

Acknowledgments: This work was supported by the Global Change Research Institute of the Czech Academy of Sciences. We thank the editors and anonymous reviewers for comments that helped to improve this manuscript. We also thank the gardeners and fruit grower who allowed us to use their gardens and orchards as study sites, Martin Markovic for help with editing the references and Keith Raymond Edwards for English corrections of the text.

Conflicts of Interest: The authors declare no conflict of interest. The funders had no role in the design of the study; in the collection, analyses, or interpretation of data; in the writing of the manuscript, or in the decision to publish the results.

\section{References}

1. Straka, J.; Bogusch, P. Anthophila. In Red List of Threatened Species of the Czech Republic. Invertebrates; Hejda, R., Farkač, J., Chobot, K., Eds.; Nature Conservation Agency of the Czech Republic: Prague, Czech Republic, 2017; Volume 36, pp. 236-249. Available online: https://www.ochranaprirody.cz/res/archive/372/058766.pdf (accessed on 26 September 2020).

2. Biesmeijer, J.C.; Roberts, S.P.M.; Reemer, M.; Ohlemüller, R.; Edwards, M.; Peeters, T.; Schaffers, A.P.; Potts, S.G.; Kleukers, R.; Thomas, C.D.; et al. Parallel declines in pollinators and insect-pollinated plants in Britain and the Netherlands. Science 2006, 313, 351-354. [CrossRef] [PubMed]

3. Carvalheiro, L.G.; Kunin, W.E.; Keil, P.; Aguirre-Gutiérrez, J.; Ellis, W.N.; Fox, R.; Groom, Q.; Hennekens, S.; Van Landuyt, W.; Maes, D.; et al. Species richness declines and biotic homogenisation have slowed down for NW -European pollinators and plants. Ecol. Lett. 2013, 16, 870-878. [CrossRef] [PubMed]

4. Ollerton, J.; Erenler, H.; Edwards, M.; Crockett, R. Extinctions of aculeate pollinators in Britain and the role of large-scale agricultural changes. Science 2014, 346, 1360-1362. [CrossRef]

5. Goulson, D.; Nicholls, E.; Botías, C.; Rotheray, E.L. Bee declines driven by combined stress from parasites, pesticides, and lack of flowers. Science 2015, 347, 1255957. [CrossRef] 
6. Powney, G.D.; Carvell, C.; Edwards, M.; Morris, R.K.A.; Roy, H.E.; Woodcock, B.A.; Isaac, N.J.B. Widespread losses of pollinating insects in Britain. Nat. Commun. 2019, 10, 1-6. [CrossRef]

7. Klein, A.-M.; Vaissière, B.E.; Cane, J.H.; Steffan-Dewenter, I.; Cunningham, S.A.; Kremen, C.; Tscharntke, T. Importance of pollinators in changing landscapes for world crops. Proc. R. Soc. B Biol. Sci. 2007, 274, 303-313. [CrossRef]

8. Garibaldi, L.A.; Steffan-Dewenter, I.; Winfree, R.; Aizen, M.A.; Bommarco, R.; Cunningham, S.A.; Kremen, C.; Carvalheiro, L.G.; Harder, L.D.; Afik, O.; et al. Wild pollinators enhance fruit set of crops regardless of honey bee abundance. Science 2013, 339, 1608-1611. [CrossRef]

9. Matteson, K.C.; Ascher, J.S.; Langellotto, G.A. Bee Richness and abundance in New York City urban gardens. Ann. Entomol. Soc. Am. 2008, 101, 140-150. [CrossRef]

10. Osborne, J.L.; Martin, A.P.; Shortall, C.R.; Todd, A.D.; Goulson, D.; Knight, M.E.; Hale, R.J.; Sanderson, R.A. Quantifying and comparing bumblebee nest densities in gardens and countryside habitats. J. Appl. Ecol. 2007, 45, 784-792. [CrossRef]

11. Samnegård, U.; Persson, A.S.; Smith, H.G. Gardens benefit bees and enhance pollination in intensively managed farmland. Biol. Conserv. 2011, 144, 2602-2606. [CrossRef]

12. Baldock, K.C.R.; Goddard, M.A.; Hicks, D.M.; Kunin, W.E.; Mitschunas, N.; Osgathorpe, L.M.; Potts, S.G.; Robertson, K.M.; Scott, A.V.; Stone, G.N.; et al. Where is the UK's pollinator biodiversity? The importance of urban areas for flower-visiting insects. Proc. R. Soc. B Biol. Sci. 2015, 282, 20142849. [CrossRef] [PubMed]

13. Langellotto, G.A.; Melathopoulos, A.P.; Messer, I.; Anderson, A.; McClintock, N.; Costner, L. Garden pollinators and the potential for ecosystem service flow to urban and peri-urban agriculture. Sustainability 2018, 10, 2047. [CrossRef]

14. Ackerman, K.; Conard, M.; Culligan, P.; Plunz, R.; Sutto, M.-P.; Whittinghill, L. Sustainable food systems for future cities: The potential of urban agriculture. Econ. Soc. Rev. 2014, 45, 189-206.

15. Lowenstein, D.M.; Matteson, K.C.; Minor, E.S. Diversity of wild bees supports pollination services in an urbanized landscape. Oecologia 2015, 179, 811-821. [CrossRef]

16. Van Tuijl, E.; Hospers, G.-J.; Berg, L.V.D. Opportunities and challenges of urban agriculture for sustainable city development. Eur. Spat. Res. Policy 2018, 25, 5-22. [CrossRef]

17. Botías, C.; David, A.; Horwood, J.; Abdulsada, A.K.; Nicholls, E.; Hill, E.M.; Goulson, D. Neonicotinoid residues in wildflowers, a potential route of chronic exposure for bees. Environ. Sci. Technol. 2015, 49, 12731-12740. [CrossRef]

18. David, A.; Botías, C.; Abdul-Sada, A.; Nicholls, E.; Rotheray, E.L.; Hill, E.M.; Goulson, D. Widespread contamination of wildflower and bee-collected pollen with complex mixtures of neonicotinoids and fungicides commonly applied to crops. Environ. Int. 2016, 88, 169-178. [CrossRef]

19. Long, E.Y.; Krupke, C.H. Non-cultivated plants present a season-long route of pesticide exposure for honey bees. Nat. Commun. 2016, 7, 11629. [CrossRef]

20. Wood, T.J.; Goulson, D. The environmental risks of neonicotinoid pesticides: A review of the evidence post 2013. Environ. Sci. Pollut. Res. 2017, 24, 17285-17325. [CrossRef]

21. Girolami, V.; Mazzon, L.; Squartini, A.; Mori, N.; Marzaro, M.; Di Bernardo, A.; Greatti, M.; Giorio, C.; Tapparo, A. Translocation of neonicotinoid insecticides from coated seeds to seedling guttation drops: A novel way of intoxication for bees. J. Econ. Entomol. 2009, 102, 1808-1815. [CrossRef] [PubMed]

22. Kopit, A.M.; Pitts-Singer, T.L. Routes of pesticide exposure in solitary, cavity-nesting bees. Environ. Entomol. 2018, 47, 499-510. [CrossRef]

23. Anderson, N.L.; Harmon-Threatt, A.N. Chronic contact with realistic soil concentrations of imidacloprid affects the mass, immature development speed, and adult longevity of solitary bees. Sci. Rep. 2019, 9, 1-9. [CrossRef] [PubMed]

24. Sgolastra, F.; Hinarejos, S.; Pitts-Singer, T.L.; Boyle, N.K.; Joseph, T.; Lūckmann, J.; Raine, N.E.; Singh, R.; Williams, N.M.; Bosch, J. Pesticide exposure assessment paradigm for solitary bees. Environ. Entomol. 2019, 48, 22-35. [CrossRef] [PubMed]

25. Thompson, H.M. Risk assessment for honey bees and pesticides-recent developments and 'new issues'. Pest. Manag. Sci. 2010, 66, 1157-1162. [CrossRef]

26. Sánchez-Bayo, F.; Goulson, D.; Pennacchio, F.; Nazzi, F.; Goka, K.; Desneux, N. Are bee diseases linked to pesticides?-A brief review. Environ. Int. 2016, 89-90, 7-11. [CrossRef] 
27. Alkassab, A.T.; Kirchner, W.H. Sublethal exposure to neonicotinoids and related side effects on insect pollinators: Honeybees, bumblebees, and solitary bees. J. Plant. Dis. Prot. 2017, 124, 1-30. [CrossRef]

28. Yoder, J.A.; Jajack, A.J.; Rosselot, A.E.; Smith, T.J.; Yerke, M.C.; Sammataro, D. Fungicide contamination reduces beneficial fungi in bee bread based on an area-wide field study in honey bee, Apis mellifera, colonies. J. Toxicol. Environ. Heal. Part. A 2013, 76, 587-600. [CrossRef]

29. Kakumanu, M.L.; Reeves, A.M.; Anderson, T.D.; Rodrigues, R.R.; Williams, M.A. Honey bee gut microbiome is altered by in-hive pesticide exposures. Front. Microbiol. 2016, 7, 1255. [CrossRef]

30. Rouzé, R.; Moné, A.; Delbac, F.; Belzunces, L.; Blot, N. The honeybee gut microbiota is altered after chronic exposure to different families of insecticides and infection by Nosema ceranae. Microbes Environ. 2019, 34, 226-233. [CrossRef]

31. Dai, P.; Yan, Z.; Ma, S.; Yang, Y.; Wang, Q.; Hou, C.; Wu, Y.; Liu, Y.; Diao, Q. The herbicide glyphosate negatively affects midgut bacterial communities and survival of honey bee during larvae reared in vitro. J. Agric. Food Chem. 2018, 66, 7786-7793. [CrossRef] [PubMed]

32. Motta, E.V.S.; Raymann, K.; Moran, N.A. Glyphosate perturbs the gut microbiota of honey bees. Proc. Natl. Acad. Sci. USA 2018, 115, 10305-10310. [CrossRef] [PubMed]

33. Daisley, B.A.; Chmiel, J.A.; Pitek, A.P.; Thompson, G.J.; Reid, G. Missing microbes in bees: How systematic depletion of key symbionts erodes immunity. Trends Microbiol. 2020. [CrossRef] [PubMed]

34. López, J.H.; Krainer, S.; Engert, A.; Schuehly, W.; Riessberger-Gallé, U.; Crailsheim, K. Sublethal pesticide doses negatively affect survival and the cellular responses in American foulbrood-infected honeybee larvae. Sci. Rep. 2017, 7, srep40853. [CrossRef]

35. DeGrandi-Hoffman, G.; Chen, Y.P.; Simonds, R. The effects of pesticides on queen rearing and virus titers in honey bees (Apis mellifera L.). Insects 2013, 4, 71-89. [CrossRef]

36. Simon-Delso, N.; Martin, G.S.; Bruneau, E.; Minsart, L.-A.; Mouret, C.; Hautier, L. Honeybee colony disorder in crop areas: The role of pesticides and viruses. PLoS ONE 2014, 9, e103073. [CrossRef]

37. Straub, L.; Williams, G.R.; Vidondo, B.; Khongphinitbunjong, K.; Retschnig, G.; Schneeberger, A.; Chantawannakul, P.; Dietemann, V.; Neumann, P. Neonicotinoids and ectoparasitic mites synergistically impact honeybees. Sci. Rep. 2019, 9, 1-10. [CrossRef]

38. Potts, S.G.; Imperatriz-Fonseca, V.; Ngo, H.T.; Aizen, M.A.; Biesmeijer, J.C.; Breeze, S.G.P.T.D.; Dicks, L.V.; Garibaldi, L.A.; Hill, R.; Settele, J.; et al. Safeguarding pollinators and their values to human well-being. Nat. Cell Biol. 2016, 540, 220-229. [CrossRef]

39. Sanchez-Bayo, F.; Goka, K. Pesticide residues and bees-A risk assessment. PLoS ONE 2014, 9, e94482. [CrossRef]

40. Feltham, H.; Park, K.; Goulson, D. Field realistic doses of pesticide imidacloprid reduce bumblebee pollen foraging efficiency. Ecotoxicology 2014, 23, 317-323. [CrossRef]

41. Sandrock, C.; Tanadini, L.G.; Pettis, J.S.; Biesmeijer, J.C.; Potts, S.G.; Neumann, P.G. Sublethal neonicotinoid insecticide exposure reduces solitary bee reproductive success. Agric. For. Entomol. 2013, 16, 119-128. [CrossRef]

42. Rundlöf, M.; Andersson, G.K.S.; Bommarco, R.; Fries, I.; Hederström, V.; Herbertsson, L.; Jonsson, O.; Klatt, B.K.; Pedersen, T.R.; Yourstone, J.; et al. Seed coating with a neonicotinoid insecticide negatively affects wild bees. Nat. Cell Biol. 2015, 521, 77-80. [CrossRef] [PubMed]

43. Stanley, D.A.; Smith, K.E.; Raine, N.E. Bumblebee learning and memory is impaired by chronic exposure to a neonicotinoid pesticide. Sci. Rep. 2015, 5, 16508. [CrossRef] [PubMed]

44. Heard, M.S.; Baas, J.; Dorne, J.-L.; Lahive, E.; Robinson, A.G.; Rortais, A.; Spurgeon, D.J.; Svendsen, C.; Hesketh, H. Comparative toxicity of pesticides and environmental contaminants in bees: Are honey bees a useful proxy for wild bee species? Sci. Total. Environ. 2017, 578, 357-365. [CrossRef]

45. Woodcock, B.A.; Bullock, J.M.; Shore, R.F.; Heard, M.S.; Pereira, M.G.; Redhead, J.; Ridding, L.E.; Dean, H.; Sleep, D.; Henrys, P.A.; et al. Country-specific effects of neonicotinoid pesticides on honey bees and wild bees. Science 2017, 356, 1393-1395. [CrossRef]

46. Alkassab, A.T.; Kunz, N.; Bischoff, G.; Pistorius, J. Comparing response of buff-tailed bumblebees and red mason bees to application of a thiacloprid-prochloraz mixture under semi-field conditions. Ecotoxicology 2020, 29, 846-855. [CrossRef] 
47. Azpiazu, C.; Bosch, J.; Viñuela, E.; Medrzycki, P.; Teper, D.; Sgolastra, F. Chronic oral exposure to field-realistic pesticide combinations via pollen and nectar: Effects on feeding and thermal performance in a solitary bee. Sci. Rep. 2019, 9, 1-11. [CrossRef]

48. Robinson, A.; Hesketh, H.; Lahive, E.; Horton, A.A.; Svendsen, C.; Rortais, A.; Dorne, J.L.; Baas, J.; Heard, M.S.; Spurgeon, D.J. Comparing bee species responses to chemical mixtures: Common response patterns? PLoS ONE 2017, 12, e0176289. [CrossRef] [PubMed]

49. Botías, C.; David, A.; Hill, E.M.; Goulson, D. Quantifying exposure of wild bumblebees to mixtures of agrochemicals in agricultural and urban landscapes. Environ. Pollut. 2017, 222, 73-82. [CrossRef]

50. Lentola, A.; David, A.; Abdul-Sada, A.; Tapparo, A.; Goulson, D.; Hill, E.M. Ornamental plants on sale to the public are a significant source of pesticide residues with implications for the health of pollinating insects. Environ. Pollut. 2017, 228, 297-304. [CrossRef]

51. Cameron, R.W.F.; Blanuša, T.; Taylor, J.E.; Salisbury, A.; Halstead, A.J.; Henricot, B.; Thompson, K. The domestic garden-Its contribution to urban green infrastructure. Urban. For. Urban. Green. 2012, 11, 129-137. [CrossRef]

52. Jehlička, P.; Kostelecký, T.; Smith, J. Food self-provisioning in Czechia: Beyond coping strategy of the poor: A response to Alber and Kohler's 'informal food production in the enlarged European Union' (2008). Soc. Indic. Res. 2012, 111, 219-234. [CrossRef]

53. Schoen, V.; Caputo, S.; Blythe, C. Valuing physical and social output: A Rapid assessment of a London community garden. Sustainability 2020, 12, 5452. [CrossRef]

54. Egerer, M.; Cecala, J.M.; Cohen, H. Wild bee conservation within urban gardens and nurseries: Effects of local and landscape management. Sustainability 2019, 12, 293. [CrossRef]

55. Robbins, P.; Polderman, A.; Birkenholtz, T. Lawns and toxins: An ecology of the city. Cities 2001, 18, 369-380. [CrossRef]

56. Peters, B.; Gao, Z.; Zumkier, U. Large-scale monitoring of effects of clothianidin-dressed oilseed rape seeds on pollinating insects in Northern Germany: Effects on red mason bees (Osmia bicornis). Ecotoxicology 2016, 25, 1679-1690. [CrossRef]

57. Rolke, D.; Persigehl, M.; Peters, B.; Sterk, G.; Blenau, W. Large-scale monitoring of effects of clothianidin-dressed oilseed rape seeds on pollinating insects in northern Germany: Residues of clothianidin in pollen, nectar and honey. Ecotoxicology 2016, 25, 1691-1701. [CrossRef]

58. Ruddle, N.; Elston, C.; Klein, O.; Hamberger, A.; Thompson, H.M. Effects of exposure to winter oilseed rape grown from thiamethoxam-treated seed on the red mason beeOsmia bicornis. Environ. Toxicol. Chem. 2018, 37, 1071-1083. [CrossRef]

59. Dietzsch, A.C.; Kunz, N.; Wirtz, I.P.; Stähler, M.; Heimbach, U.; Pistorius, J. Does winter oilseed rape grown from clothianidin-coated seeds affect experimental populations of mason bees and bumblebees? A semi-field and field study. J. Consum. Prot. Food Saf. 2019, 14, 223-238. [CrossRef]

60. Eeraerts, M.; Pisman, M.; Vanderhaegen, R.; Meeus, I.; Smagghe, G. Recommendations for standardized oral toxicity test protocols for larvae of solitary bees, Osmia spp. Apidologie 2019, 51, 48-60. [CrossRef]

61. Raw, A. The biology of the solitary bee Osmia rufa (L.) (Megachilidae). Ecol. Entomol. 2009, 124, $213-229$. [CrossRef]

62. Raw, A. Pollen preferences of three osmia species (Hymenoptera). Oikos 1974, 25, 54. [CrossRef]

63. Radmacher, S.; Strohm, E. Factors affecting offspring body size in the solitary bee Osmia bicornis (Hymenoptera, Megachilidae). Apidologie 2009, 41, 169-177. [CrossRef]

64. Jauker, F.; Peter, F.; Wolters, V.; Diekötter, T. Early reproductive benefits of mass-flowering crops to the solitary bee Osmia rufa outbalance post-flowering disadvantages. Basic Appl. Ecol. 2012, 13, 268-276. [CrossRef]

65. Holzschuh, A.; Dormann, C.F.; Tscharntke, T.; Steffan-Dewenter, I. Mass-flowering crops enhance wild bee abundance. Oecologia 2013, 172, 477-484. [CrossRef]

66. Persson, A.S.; Mazier, F.; Smith, H.G. When beggars are choosers-How nesting of a solitary bee is affected by temporal dynamics of pollen plants in the landscape. Ecol. Evol. 2018, 8, 5777-5791. [CrossRef]

67. Gathmann, A.; Tscharntke, T. Foraging ranges of solitary bees. J. Anim. Ecol. 2002, 71, 757-764. [CrossRef]

68. Hofmann, M.M.; Fleischmann, A.; Renner, S.S. Foraging distances in six species of solitary bees with body lenghts of 6 to $15 \mathrm{~mm}$, inferred from individual tagging, suggest $150 \mathrm{~m}$-rule-of-thumb for flower strip distances. J. Hymenopt. Res. 2020, 77, 105-117. [CrossRef] 
69. ČÚZK (Czech Office for Surveying, Mapping and Cadastre). Base Map of the Czech Republic 1:10,000: WMS View Service-ZM 10. Available online: https://geoportal.cuzk.cz/(S(naqemgklqsek3b3ydggftiqe))/ Default.aspx?menu=3115\&mode=TextMeta\&side=wms.verejne\&metadataID=CZ-CUZK-WMS-ZM10P\&metadataXSL=metadata.sluzba (accessed on 25 September 2020).

70. Faegri, K.; Iversen, J. Textbook of Pollen Analysis, 4th ed.; John Wiley and Sons: Chichester, UK, 1989; p. 328.

71. Beug, H.-J. Leitfaden der Pollenbestimmung für Mitteleuropa und angrenzende Gebiete, 1st ed.; Verlag Dr. Friedrich Pfeil: München, Germany, 2004; p. 542.

72. Anastassiades, M.; Lehotay, S.J.; Štajnbaher, D.; Schenck, F.J. Fast and easy multiresidue method employing acetonitrile extraction/partitioning and "dispersive solid-phase extraction" for the determination of pesticide residues in produce. J. AOAC Int. 2003, 86, 412-431. [CrossRef]

73. R Core Team. R: A Language and Environment for Statistical Computing. R Foundation for Statistical Computing. Vienna, Austria, 2019. Available online: http://www.R-project.org/ (accessed on 25 September 2020).

74. Kasiotis, K.M.; Anagnostopoulos, C.; Anastasiadou, P.; Machera, K. Pesticide residues in honeybees, honey and bee pollen by LC-MS/MS screening: Reported death incidents in honeybees. Sci. Total. Environ. 2014, 633-642. [CrossRef]

75. Calatayud-Vernich, P.; Calatayud, F.; Simó, E.; Picó, Y. Occurrence of pesticide residues in Spanish beeswax. Sci. Total. Environ. 2017, 605, 745-754. [CrossRef] [PubMed]

76. Tosi, S.; Costa, C.; Vesco, U.; Quaglia, G.; Guido, G. A 3-year survey of Italian honey bee-collected pollen reveals widespread contamination by agricultural pesticides. Sci. Total. Environ. 2018, 615, 208-218. [CrossRef]

77. Böhme, F.; Bischoff, G.; Zebitz, C.P.W.; Rosenkranz, P.; Wallner, K. Pesticide residue survey of pollen loads collected by honeybees (Apis mellifera) in daily intervals at three agricultural sites in South Germany. PLoS ONE 2018, 13, e0199995. [CrossRef] [PubMed]

78. Hladik, M.L.; Vandever, M.; Smalling, K.L. Exposure of native bees foraging in an agricultural landscape to current-use pesticides. Sci. Total. Environ. 2016, 542, 469-477. [CrossRef] [PubMed]

79. Thompson, H.M.; Fryday, S.L.; Harkin, S.; Milner, S. Potential impacts of synergism in honeybees (Apis mellifera) of exposure to neonicotinoids and sprayed fungicides in crops. Apidologie 2014, 45, 545-553. [CrossRef]

80. Schmuck, R.; Stadler, T.; Schmidt, H.-W. Field relevance of a synergistic effect observed in the laboratory between an EBI fungicide and a chloronicotinyl insecticide in the honeybee (Apis mellifera L., Hymenoptera). Pest. Manag. Sci. 2003, 59, 279-286. [CrossRef]

81. Iwasa, T.; Motoyama, N.; Ambrose, J.T.; Roe, R.M. Mechanism for the differential toxicity of neonicotinoid insecticides in the honey bee, Apis mellifera. Crop. Prot. 2004, 23, 371-378. [CrossRef]

82. Zhu, W.; Schmehl, D.R.; Mullin, C.A.; Frazier, J.L. Four common pesticides, their mixtures and a formulation solvent in the hive environment have high oral toxicity to honey bee larvae. PLoS ONE 2014, 9, e77547. [CrossRef]

83. Biddinger, D.J.; Robertson, J.L.; Mullin, C.; Frazier, J.; Ashcraft, S.A.; Rajotte, E.G.; Joshi, N.K.; Vaughn, M. Comparative toxicities and synergism of apple orchard pesticides to Apis mellifera (L.) and Osmia cornifrons (Radoszkowski). PLoS ONE 2013, 8, e72587. [CrossRef]

84. Sgolastra, F.; Medrzycki, P.; Bortolotti, L.; Renzi, M.T.; Tosi, S.; Bogo, G.; Teper, D.; Porrini, C.; Molowny-Horas, R.; Bosch, J. Synergistic mortality between a neonicotinoid insecticide and an ergosterol-biosynthesis-inhibiting fungicide in three bee species. Pest. Manag. Sci. 2016, 73, 1236-1243. [CrossRef]

85. Sgolastra, F.; Arnan, X.; Cabbri, R.; Isani, G.; Medrzycki, P.; Teper, D.; Bosch, J. Combined exposure to sublethal concentrations of an insecticide and a fungicide affect feeding, ovary development and longevity in a solitary bee. Proc. R. Soc. B Biol. Sci. 2018, 285, 20180887. [CrossRef] [PubMed]

86. Steffan-Dewenter, I.; Kuhn, A. Honeybee foraging in differentially structured landscapes. Proc. R. Soc. B Biol. Sci. 2003, 270, 569-575. [CrossRef] [PubMed]

87. Wolf, S.; Moritz, R.F.A. Foraging distance in Bombus terrestris L. (Hymenoptera: Apidae). Apidologie 2008, 39, 419-427. [CrossRef] 
88. Redhead, J.W.; Dreier, S.; Bourke, A.F.G.; Heard, M.S.; Jordan, W.C.; Sumner, S.; Wang, J.; Carvell, C. Effects of habitat composition and landscape structure on worker foraging distances of five bumble bee species. Ecol. Appl. 2016, 26, 726-739. [CrossRef] [PubMed]

89. Jehlička, P.; Daněk, P.; Vávra, J. Rethinking resilience: Home gardening, food sharing and everyday resistance. Can. J. Dev. Stud. 2018, 40, 511-527. [CrossRef]

90. Jehlička, P.; Smith, J. Sustainability and the "urban peasant": Rethinking the cultural politics of food self-provisioning in the Czech Republic. In New Perspectives on Consumer Culture Theory and Research; Zahrádka, P., Sedláková, R., Eds.; Cambridge Scholars Publishing: Newcastle upon Tyne, UK, 2012; pp. 78-96.

91. Russo, L.; Park, M.; Blitzer, E.; Danforth, B. Flower handling behavior and abundance determine the relative contribution of pollinators to seed set in apple orchards. Agric. Ecosyst. Environ. 2017, 246, 102-108. [CrossRef]

92. Krupke, C.H.; Hunt, G.J.; Eitzer, B.D.; Andino, G.; Given, K. Multiple routes of pesticide exposure for honey bees living near agricultural fields. PLoS ONE 2012, 7, e29268. [CrossRef]

93. McArt, S.H.; Fersch, A.A.; Milano, N.J.; Truitt, L.L.; Böröczky, K. High pesticide risk to honey bees despite low focal crop pollen collection during pollination of a mass blooming crop. Sci. Rep. 2017, 7, srep46554. [CrossRef]

94. Bonmatin, J.-M.; Giorio, C.; Girolami, V.; Goulson, D.; Kreutzweiser, D.P.; Krupke, C.; Liess, M.; Long, E.; Marzaro, M.; Mitchell, E.A.D.; et al. Environmental fate and exposure; neonicotinoids and fibronil. Environ. Sci. Pollut. Res. 2015, 22, 35-67. [CrossRef]

95. Vijver, M.G.; Hunting, E.R.; Nederstigt, T.A.; Tamis, W.L.; Brink, P.V.D.; Van Bodegom, P.M. Postregistration monitoring of pesticides is urgently required to protect ecosystems. Environ. Toxicol. Chem. 2017, 36, 860-865. [CrossRef]

96. Hvězdová, M.; Kosubová, P.; Košíková, M.; Scherr, K.E.; Šimek, Z.; Brodský, L.; Šudoma, M.; Škulcová, L.; Sáňka, M.; Svobodová, M.; et al. Currently and recently used pesticides in Central European arable soils. Sci. Total. Environ. 2018, 361-370. [CrossRef] [PubMed]

97. Silva, V.; Mol, H.G.J.; Zomer, P.; Tienstra, M.; Ritsema, C.J.; Geissen, V. Pesticide residues in European agricultural soil-A hidden reality unfolded. Sci. Total Environ. 2019, 653, 1532-1545. [CrossRef] [PubMed]

98. Artz, D.R.; Pitts-Singer, T.L. Effects of fungicide and adjuvant sprays on nesting behavior in two managed solitary bees, Osmia lignaria and Megachile rotundata. PLoS ONE 2015, 10, e0135688. [CrossRef] [PubMed]

99. EC (European Commission). Commission Implementing Regulation (EU) 2018/1865 of 28 November 2018 concerning the non-renewal of approval of the active substance propiconazole, in accordance with Regulation (EC) No 1107/2009 of the European Parliament and of the Council concerning the placing of plant protection products on the market, and amending Commission Implementing Regulation (EU) No 540/2011. Off. J. Eur. Union 2018, 304, 6-9. Available online: https://eur-lex.europa.eu/legal-content/EN/TXT/?qid= 1543505797502\&uri=CELEX:32018R1865 (accessed on 25 September 2020).

100. Rondeaux, G.; Sánchez-Bayo, F.; Tennekes, H.A.; Decourtye, A.; Ramírez-Romero, R.; Desneux, N. Delayed and time-cumulative toxicity of imidacloprid in bees, ants and termites. Sci. Rep. 2014, 4, srep05566. [CrossRef]

101. Crall, J.D.; Switzer, C.M.; Oppenheimer, R.L.; Versypt, A.N.F.; Dey, B.; Brown, A.; Eyster, M.; Guérin, C.; Pierce, N.E.; Combes, S.A.; et al. Neonicotinoid exposure disrupts bumblebee nest behavior, social networks, and thermoregulation. Science 2018, 362, 683-686. [CrossRef]

102. Erban, T.; Sopko, B.; Talacko, P.; Harant, K.; Kadlikova, K.; Halesova, T.; Riddellova, K.; Pekas, A. Chronic exposure of bumblebees to neonicotinoid imidacloprid suppresses the entire mevalonate pathway and fatty acid synthesis. J. Proteom. 2019, 196, 69-80. [CrossRef]

103. EC (European Commission). Final Renewal Report for the Active Substance Thiacloprid Finalised in the Standing Committee on Plants, Animals, Food and Feed at Its Meeting on 22 October 2019 in View of the Non-Renewal of the Approval of Thiacloprid as Active Substance in Accordance with Regulation (EC) No 1107/2009. Thiacloprid, SANTE/10450/2019 Rev. 1, 22 October 2019; Directorate-General for Health and Food Safety: Bruxelles, Belgium, 2019; Available online: https:/ec.europa.eu/food/plant/pesticides/eupesticides-database/public/?event=activesubstance.ViewReview\&id=1788 (accessed on 25 September 2020). 
104. EC (European Commission). Commission Implementing Regulation (EU) 2020/18 of 10 January 2020 concerning the non-renewal of the approval of the active substance chlorpyrifos, in accordance with Regulation (EC) No 1107/2009 of the European Parliament and of the Council concerning the placing of plant protection products on the market, and amending the Annex to Commission Implementing Regulation (EU) No 540/2011. Off. J. Eur. Union 2020, 7, 14-16. Available online: https://eur-lex.europa.eu/legal-content/EN/ TXT/?qid=1578929027090\&uri=CELEX:32020R0018 (accessed on 25 September 2020).

105. EC (European Commission). Final Renewal Report for the Active Substance Methiocarb Finalised in the Standing Committee on Plants, Animals, Food and Feed at Its Meeting on 17 July 2019 in View of the Non-Renewal of the Approval of Methiocarb as Active Substance in Accordance with Regulation (EC) No 1107/2009. Methiocarb, SANTE/11710/2018 Rev 1, 17 July 2019; Directorate-General for Health and Food Safety: Bruxelles, Belgium, 2019; Available online: https://ec.europa.eu/food/plant/pesticides/eu-pesticides-database/public/?event= activesubstance. ViewReview\&id=1730 (accessed on 25 September 2020).

106. ČÚZK (Czech Office for Surveying, Mapping and Cadastre). Orthophotos of the Czech Republic Recent Data: WMS View Service-Orthophoto. Available online: https:/geoportal.cuzk.cz/(S(naqemgklqsek3b3ydggftiqe))/ Default.aspx?lng=EN\&menu=3121\&mode=TextMeta\&side=wms.verejne\&metadataID=CZ-CUZK-WMSORTOFOTO-P\&metadataXSL=metadata.sluzba (accessed on 25 September 2020).

Publisher's Note: MDPI stays neutral with regard to jurisdictional claims in published maps and institutional affiliations.

(C) 2020 by the authors. Licensee MDPI, Basel, Switzerland. This article is an open access article distributed under the terms and conditions of the Creative Commons Attribution (CC BY) license (http://creativecommons.org/licenses/by/4.0/). 